\title{
CLOCK wt Allele
}

National Cancer Institute

\section{Source}

National Cancer Institute. CLOCK wt Allele. NCI Thesaurus. Code C119690.

Human CLOCK wild-type allele is located in the vicinity of $4 q 12$ and is approximately 119 $\mathrm{kb}$ in length. This allele, which encodes circadian locomoter output cycles protein kaput, is involved in the regulation of circadian rhythms, histone acetylation and gene transcription. 